\title{
The European Union's Potential Contribution to Protect Marine Biodiversity in the Changing Arctic: a Roadmap
}

\author{
Nengye Liu* and Elizabeth A. Kirk**
}

\section{Introduction}

In 2012 the European Union (EU) ${ }^{1}$ published its latest Arctic policy, which indicates that "the EU should step up its engagement with its Arctic partners to jointly meet the challenge of safeguarding the environment while ensuring the sustainable development of the Arctic region”. ${ }^{2}$ The European Commission (the Commission) had previously set out the EU's interests in the Arctic and proposed action around three main policy objectives: 1) protection and preservation of the Arctic in unison with its population; 2) promotion of the sustainable use of resources; 3) enhancement of Arctic multilateral governance. ${ }^{3}$ These have received the

\footnotetext{
* Marie Curie Fellow, School of Law, University of Dundee, United Kingdom.

** Senior Lecturer, School of Law, University of Dundee, United Kingdom.

The authors would like to thank Robin Churchill, Timo Koivurova, Marten Koopmans, Frithjoff Kuepper and Elisa Morgera for their useful comments on earlier drafts.

${ }^{1}$ The EU is a unique economic and political partnership between 28 European countries that together cover much of the continent of Europe. See http://europa.eu/about-eu/index_en.htm.

${ }^{2}$ Joint Communication of the European Commission and High Representative of the European Union for Foreign Affairs and Security Policy of 26 June 2012 on Developing a European Union Policy towards the Arctic Region: Progress since 2008 and Next Steps, JOIN (2012) 19, 2.

${ }^{3}$ European Commission Communication of 20 Nov 2008 on the European Union and the Arctic Region, COM (2008) 763.
} 
support of the Council of the European Union (the Council) ${ }^{4}$ and the European Parliament. ${ }^{5}$ When coupled with the EU's pledge to meet the international 2020 biodiversity goals and objectives agreed under the Convention on Biological Diversity $(\mathrm{CBD})^{6}$, the objectives give strong grounds for EU action to protect marine biodiversity ${ }^{7}$ in the Arctic. If the EU's 2020 biodiversity pledge is to be met, action will have to be taken both within the EU and at the global level since the EU derives significant benefits from global biodiversity and is at the same time responsible for some of the loss and degradation that occurs beyond its borders, notably due to its unsustainable consumption patterns. ${ }^{8}$ Addressing the protection of marine biodiversity in the Arctic goes someway to meeting these goals and the EU's Arctic objectives.

It is not, however, clear where or how exactly the EU could make its contribution to these goals. Climate change is the primary threat to the unique and fragile Arctic ecosystem as it has both direct and indirect impacts. ${ }^{9}$ Climate change is also already leading to increased human activities, which may bring threats to Arctic marine biodiversity. Threats may arise as a result of, for example, oil pollution, noise pollution and litter from shipping and extractive industries; or fishing interfering with the precise mix of species within the Arctic system, whether through

\footnotetext{
${ }^{4}$ Council of the European Union Conclusions of 8 December 2009 on Arctic Issues.

${ }^{5}$ European Parliament Resolution of 20 January 2011 on a Sustainable EU Policy for the High North, 2009/2214(INI).

${ }^{6}$ COP 10 Decision X/2, The Strategic Plan for Biodiversity 2011-2020 and the Aichi Biodiversity Targets, Nagoya, Japan, 18 -29 October 2010.

7 "Biological diversity" means the variability among living organisms from all sources including, inter alia, terrestrial, marine and other aquatic ecosystems and the ecological complexes of which they are part; this includes diversity within species, between species and of ecosystems. Convention on Biological Diversity, Art. 2 Use of Terms.

${ }^{8}$ European Commission Communication of 3 May 2011 on Our Life Insurance, Our Natural Capital: an EU Biodiversity Strategy to 2020, COM (2011) 244, 7.

${ }^{9}$ Arctic Climate Impact Assessment, 2005, Cambridge University Press, 770.
} 
overfishing or otherwise. ${ }^{10}$ Increasing human activities on land arising from the need to service the new Arctic industries may also affect the marine environment through, for example landbased pollution.

These threats potentially provide the EU with fertile ground for action, but some of the international regimes that the EU could influence are likely to provide more fruitful locations for its efforts than others. For example, while the main focus of action vis à vis climate change will be the global climate change regime, ${ }^{11}$ the likelihood of success in influencing the development of aspects of the climate change regime to specifically protect marine biodiversity in the Arctic is quite slim. The EU might wish to promote an agreement to minimize the impact of climate change mitigation measures on Arctic marine biodiversity - a specialized version of the Marrakesh Accords ${ }^{12}$ - but not only might this in effect duplicate an existing agreement, it would also require a considerable expenditure of political capital for a very uncertain return. Similarly, addressing marine pollution from land-based activities requires significant interference with the domestic sovereignty of Arctic States. One option might be to support the existing Arctic regional plan of action on marine pollution from land-based activities (RPA). For example, the EU could provide funding or scientific support for particular projects under the RPA. The ability of the EU to do so is, however, heavily dependent upon the willingness of the Arctic States to cooperate. A better option may be for the EU to focus on a particular aspect of marine pollution from land-based activities, such as pollution from heavy metals, or

\footnotetext{
${ }^{10}$ Arctic Biodiversity Trend 2010 - Selected Indicators of Change. CAFF International Secretariat, Akureyri, Iceland. May 2010, 15.

${ }^{11}$ United Nations Framework Convention on Climate Change 1992 (1994) 1771 UNTS 107 and subsidiary documents.

${ }^{12}$ UNFCCC Decision II/CP. The Marrakech Accords is a set of agreements reached at the 7th Conference of the Parties (COP7) to the United Nations Framework Convention on Climate Change, held in 2001, on the rules of meeting the targets set out in the Kyoto Protocol.
} 
marine debris and promote a global agreement ${ }^{13}$ in that area akin to the persistent organic pollutants ${ }^{14}$ and mercury conventions. ${ }^{15}$ In the absence of such a possible area of focus, the likelihood of the EU's actions having significant impact in relation to the protection of Arctic biodiversity from this source of pollution is likely to be limited. The potential difficulties in obtaining agreement in these areas suggest that the EU should focus upon other areas. Possible areas of focus are the global biodiversity regime, shipping, fisheries and offshore oil and gas operations. It is believed by the authors that these are fruitful areas for EU action. Not only have shipping, fisheries and oil and gas been identified as major emerging challenges for Arctic marine biodiversity, ${ }^{16}$ but the EU either has exclusive competence in policy making (fisheries),${ }^{17}$ or successful experience of influencing international decision-making in the past decade (shipping). ${ }^{18}$ This article therefore provides a roadmap for possible EU action in these areas. Firstly the EU's competence in the Arctic is briefly introduced. Then the discussion turns to the EU's potential external and internal actions in shipping, fisheries and offshore oil and

\footnotetext{
${ }^{13}$ On marine debris see the Global Programme of Action for the Protection of the Marine Environment from Land-Based Activities (UNEP (OCA)/LBA/IG.2/7, 5 December 1995); the Honolulu Commitment (endorsed at the Fifth International Marine Debris Conference (5IMDC)) and The Honolulu Strategy: A Global Framework for Prevention and Management of Marine Debris.

${ }^{14}$ United Nations Environment Programme (UNEP): Stockholm Convention on Persistent Organic Pollutants (2001) 40 (3) ILM 532-563.

${ }^{15}$ Minamata Convention on Mercury (Geneva, 19 January 2013; not yet in force)

${ }^{16}$ Arctic Biodiversity Trend 2010 - Selected Indicators of Change. CAFF International Secretariat, Akureyri, Iceland. May 2010, 15.

${ }^{17}$ Consolidated Versions of the Treaty on the Functioning of the European Union (TFEU), [2010] OJ C83/47, Art. 3 (1) (d): The Union shall have exclusive competence in the conservation of marine biological resources under the common fisheries policy

${ }^{18}$ For details, see Nengye Liu, Frank Maes, ‘The European Union and International Maritime Organization: EU’s External Influence on the Prevention of Vessel-Source Pollution’ (2010) 41 (4) Journal of Maritime Law and Commerce 581-594.
} 
gas operations that could possibly enhance the international legal regime for the protection of marine biodiversity in the Arctic. The EU's role vis à vis the global biodiversity regime ${ }^{19}$ and cross cutting measures under the United Nations Convention on the Law of the Sea $(\mathrm{UNCLOS})^{20}$ are discussed together in the final part. While the CBD may seem to be the obvious place to start a discussion on the EU's role in protecting Arctic marine biodiversity, starting with the discussion of shipping, fisheries and extractive industries helps to illustrate the EU's ties with the Arctic region. These ties then help provide a justification for possible action under the CBD and cross cutting action under UNCLOS.

\section{The EU's Competence ${ }^{21}$ in the Arctic}

By any account the EU is a relatively new player in the Arctic. ${ }^{22}$ The EU has been described by some as the most dramatic case a non-Arctic organization that asserts claims to be treated as a legitimate stakeholder with regard to Arctic issues. ${ }^{23}$ While it is true that no EU Member States is a coastal State of the Arctic Ocean, (Greenland became governmentally autonomous

\footnotetext{
${ }^{19}$ See United Nations Conference on Environment and Development: Convention on Biological Diversity, (1992) 31 (4) ILM 818-841 and related agreements.

${ }^{20}$ United Nations Convention on the Law of the Sea, (1982) 21 (6) ILM 1261-1354.

${ }^{21}$ Competence is the term used in the Lisbon Treaty to describe the power the EU has to draw up policies and laws. The EU may introduce policies and laws only in relation to those areas that are set out in the treaties. The competences of the EU are divided into three categories: 1) the EU has exclusive competence (Art. 3 TFEU) (only the EU can act); 2) competences are shared between the EU and the member states (Art. 4 TFEU) (The member states can act only if the EU has chosen not to); 3) the EU has competence to support, coordinate or supplement the actions of the member states (Art. 6 TFEU) - in these areas, the EU may not adopt legally binding acts that require the member states to harmonise their laws and regulations.

22 Timo Koivurova, Kai Kokko, Sébastien Duyck, Nikolas Sellheim, Adam Stepien, 'The Present and Future Competence of the European Union in the Arctic’ (2012) 48 (4) Polar Record 361-371.

${ }^{23}$ Oran Young, ‘Arctic Governance - Pathways to the Future’ (2010) 1 (2) Arctic Review on Law and Politics 171.
} 
within Denmark ${ }^{24}$ and is not part of the EU $)^{25}$ the EU does have some ties with the Arctic. Three Arctic countries are EU Member States (Denmark, Sweden and Finland) and the EU maintains close relations with Iceland and Norway through the European Economic Area (EEA). ${ }^{26}$ Canada, Russia and the United States are also strategic partners of the EU. Although the EU's relationships with these States may not be as close as its relationships with other Arctic States, existing partnerships help strengthen the EU’s knowledge of Canadian, American and Russian negotiating positions on and interests in the Arctic. They also help ensure that the EU possesses the social capital necessary for successful international cooperation with those States. These relationships hint then at the possibilities of successful EU-Arctic State interactions whether direct or via international organizations or regimes.

It is a cardinal principle of EU law that the EU has the competence to adopt policies and legislation only to the extent that such competence has been conferred on it by the Member States through the EU Treaties. ${ }^{27}$ The EU does not have a specific Arctic mandate from its Member States. However, according to the Treaty on the European Union (TEU), the Union shall define and pursue common policies and actions, and shall work for a high degree of cooperation in all fields of international relations, in order to help develop international measures to preserve and improve the quality of the environment and the sustainable

\footnotetext{
${ }^{24}$ Art. 22 of Act No.473/2009 on Greenland’s Self-Government.

${ }^{25}$ Treaty amending, with regard to Greenland, the Treaties Establishing the European Communities [1985] OJ L29/1.

${ }^{26}$ The Agreement on the European Economic Area, which entered into force on 1 January 1994, brings together the EU Member States and the three EEA EFTA States — Iceland, Liechtenstein and Norway — in a single market, referred to as the "Internal Market".

${ }^{27}$ Consolidated Versions of the Treaty on the European Union (TEU), [2010] OJ C83/13, Art. 5(2). See also, Robin Churchill, ‘The European Union and the Challenges of Marine Governance: From Sectoral Response to Integrated Policy?’ in: Davor Vidas and Peter Johan Schei (eds.), The World Ocean in Globalisation Climate Change, Sustainable Fisheries, Biodiversity, Shipping, Regional Issues (Martinus Nijhoff, the Netherlands, 2011) 398.
} 
management of global natural resources, in order to ensure sustainable development. ${ }^{28}$ The EU has shared competence in relation to the protection of marine biodiversity in general under the environmental provisions of the Treaty on the Functioning of the European Union (TFEU). ${ }^{29}$ For example, based on Art. 175 (1), Treaty establishing the European Community (now Art. 192, TFEU), the EU adopted the Marine Strategy Framework Directive ${ }^{30}$ in 2008, which aims to achieve Good Environmental Status (GES) of the EU's marine waters by 2020 and to protect the resource base upon which marine-related economic and social activities depend.

Moreover, the EU has either exclusive or shared competences to act in several marine matters, such as shipping, fisheries and marine energy. ${ }^{31}$ Crucially this includes an exclusive competence on the conservation of marine biodiversity, under the common fisheries policy (CFP). ${ }^{32}$ This means that only the EU may legislate and adopt legally binding acts, the Member States being able to do so themselves only if so empowered by the EU or if necessary for the implementation of EU legislation. ${ }^{33}$ This competence is, however, limited in that it applies only in waters coming under the sovereignty or jurisdiction of EU Member States. ${ }^{34}$ Nevertheless,

\footnotetext{
${ }^{28}$ TEU, Art. 21 (2) (f).

${ }^{29}$ TFEU, Art. 191.

${ }^{30}$ Directive 2008/56/EC establishing a framework for community action in the field of marine environmental policy, [2008] OJ L164/19.

${ }^{31}$ TFEU, Art. 4 (2): Shared competence between the Union and the Member States applies in the following principal areas: (d) agriculture and fisheries, excluding the conservation of marine biological resources; (e) environment; (g) transport; (i) energy. See also Churchill, ibid, pp. 395-436.

${ }^{32}$ For detailed discussions see, Robin Churchill and Daniel Owen, The EC Common Fisheries Policy (Oxford University Press, UK, 2010) 130-132.

33 TFEU, Art. 2 (1).

${ }^{34}$ TFEU, Art. 3 (1) (d). For detailed discussions see, Robin Churchill and Daniel Owen, The EC Common Fisheries Policy (Oxford University Press, UK, 2010) 130-132.
} 
given that the leading European Court of Justice (ECJ) ERTA/AETR case clearly states that the Community acquires external competence when it adopts internal legislation on the same subject-matter, ${ }^{35}$ the EU also has external competence regarding fisheries to negotiate and conclude conventions with third states.

The EU declared, as a condition of joining UNCLOS that maritime transport, safety of shipping and the prevention of marine pollution contained inter alia in UNCLOS Parts II, III, V, VII and XII were to be areas of shared competences between the EU and Member States, but also subject to continuous development. ${ }^{36}$ It therefore has concrete competences to make substantial contributions to the prevention of vessel-source pollution in the Arctic. The EU has not only competence to regulate EU Member States' flag ships sailing in the Arctic, but also to legislate in the area of port state control for trans-Arctic ships utilizing any EU port. ${ }^{37}$

Lastly, with regard to EU competence in relation to oil and gas extraction, one of the clearest changes brought by the Treaty of Lisbon is that energy is now explicitly included in the list of EU competences, one mainly shared between the EU and Member States. ${ }^{38} \mathrm{EU}$ competences for environmental policy are furthermore linked with the shared competence in energy as Art. 194 of TFEU states that EU energy policy is to be set in "the context of the

\footnotetext{
${ }^{35}$ ECJ, Case C-22/70, Commission v. Council, [1971] ECR.263, Para.19: "With regard to the implementation of the provisions of the Treaty the system of internal Community measures may not therefore be separated from that of external relations”.

${ }^{36}$ Declaration Concerning the Competence of the European Community with regard to Matters Governed by the United Nations Convention on the Law of the Sea of 10 December 1982 and the Agreement of 28 July 1994 Relating to the Implementation of Part XI of the Convention, Council Decision of 23.3.1998, OJ L179 of 23.06.1998, 1.

${ }^{37}$ Timo Koivurova, Kai Kokko, Sébastien Duyck, Nikolas Sellheim, Adam Stepien, EU Competencies Affecting the Arctic, DG for External Policies Policy Department, European Parliament, 2010, 21.

${ }^{38}$ Timo Koivurova, Kai Kokko, Sébastien Duyck, Nikolas Sellheim, Adam Stepien, n 22 above, 366; TFEU, Article 4 (2).
} 
establishment and functioning of the internal market and with regard for the need to preserve and improve the environment. ${ }^{39}$

Given that the EU has been granted the power to act in these areas by its Member States, the real question then is, how can the EU exercise these powers to the benefit of Arctic marine biodiversity.

\section{The EU and Arctic Shipping}

As shipping seasons extend, Arctic shipping costs are reduced and point-to-point demand increases, Arctic maritime traffic is expected to increase.$^{40}$ According to the Arctic Marine Shipping Assessment Report 2009:

“Changes in Arctic sea ice will not only provide for possible longer seasons of navigation, but may also result in increased interaction between migrating species and ships. The most significant threat from ships to the Arctic marine ecosystem is the release of oil through accidental or illegal discharge. Additional potential impacts of Arctic ships include ship strikes on marine mammals, the introduction of alien species, disruption of migratory patterns of marine mammals and anthropogenic noise produced from marine shipping activity”. ${ }^{41}$

There is, therefore, a need for action to mitigate these impacts, so how might this be done?

The UNCLOS provides the framework for the regulation of all maritime shipping including Arctic shipping. Its provisions should be read together with the international

\footnotetext{
39 TFEU, Art. 194; See also EU Competencies Affecting the Arctic, n. 37 above, 24.

${ }^{40}$ Charles Emmerson and Glada Lahn, ‘Arctic Opening: Opportunity and Risk in the High North’, Chatham House-Lloyd’s Risk Insight Report (2012) 29.

${ }^{41}$ Arctic Council Arctic Marine Shipping Assessment 2009 Report, 9.
} 
conventions adopted under the auspices of the International Maritime Organisation (IMO): the International Convention for the Prevention of Pollution from Ships (MARPOL 73/78), ${ }^{42}$ the International Convention for the Safety of Life at Sea (SOLAS 74), ${ }^{43}$ the International Convention on the Control of Harmful Anti-fouling Systems on Ships (Anti-Fouling Convention), ${ }^{44}$ the International Convention for the Control and Management of Ships' Ballast Water and Sediments (BWM Convention, not yet entered into force), ${ }^{45}$ and the Convention on Standards of Training, Certification and Watchkeeping of Seafarers (STCW Convention). ${ }^{46}$

While these treaties provide the Arctic with as much coverage as other areas of the oceans, they leave several gaps. In particular, they do not address the need for Arctic specific measures. The Arctic is, for example, particularly sensitive to the effects of oil spills, as it takes longer to breakdown or disperse pollutants in cold environments and in areas where wave action is restricted by the presence of ice than it does in other parts of the oceans. This gives rise to the need for special IMO discharge, emission and ballast water exchange standards and for fuel content for the Arctic marine area. The melting of sea-ice also increases the risk of damage to ships by icebergs as more icebergs are freed by the melting process. Increasing numbers of vessels also give rise to the possibility of increased collisions and an increase in the number of accidents caused by poor maintenance or human error. Although some ship routing

\footnotetext{
42 International Convention for the Prevention of Pollution from Ships, (1973) 12 (6) ILM 1319-1444; Protocol of 1978 Relating to the International Convention for the Prevention of Pollution from Ships, 1973, (1978) 17 (3) ILM 546-578.

${ }^{43}$ Inter-Governmental Maritime Consultative Organization: International Convention for the Safety of Life at Sea, 1974, (1975)14 ILM 959-978.

${ }^{44}$ International Conference on the Control of Harmful Anti-Fouling Systems for Ships, AFS/CONF/26, 18 Oct 2001, Agenda item 8.

${ }^{45}$ International Convention on Ballast Water Management for Ships, BWM/CONF/36, 16 Feb 2004, Agenda item 8.

${ }^{46}$ International Convention on Standards of Training, Certification and Watchkeeping for Seafarers, 1978 (with annex), UNTS No. 23001, Vol. 1361, 1984.
} 
arrangements already exist, ${ }^{47}$ the changes in sea ice point to the need for the adoption of further ship routing arrangements in the Arctic. The presence of sea ice also gives rise to the need for special construction, design, equipment and manning (CDEM) requirements. ${ }^{48}$ Lastly, while Canada has in place zero discharge zones, ${ }^{49}$ much of the Arctic Ocean is left unprotected by such measures. One might assume that, given the fragile nature of the Arctic Ocean, most of the Ocean would have been designated as a special area in accordance with the relevant MARPOL Annexes, to protect it from discharges from ships.

Many of these issues are being addressed through the adoption of the International Code for Ships Operating in Polar Waters (the Polar Code) by the IMO. The Code covers a wide range of (but not all) matters relevant to ships operating in ice-covered waters. Thus it addresses issues pertaining to design and construction, on board equipment, operational matters such as providing for MARPOL Special Area discharge restrictions, training for seafarers, search and rescue arrangements and environmental protection. As it covers both environmental and safety ${ }^{50}$ matters, the adoption of the code is taking place in two phases. In the first part, which took place in November 2014, the IMO’s Maritime Safety Committee (MSC) addressed safety issues by adopting both the Polar Code and amendments to the International Convention for the Safety of Life at Sea (SOLAS) ${ }^{51}$ This process ensures that the mandatory safety measures provided for in the Code will come into force under the SOLAS regime. A similar process is

\footnotetext{
${ }^{47}$ See for example, the Canadian "Northern Canada Vessel Traffic Services Zone” http://www.ccggcc.gc.ca/eng/MCTS/Vtr_Arctic_Canada.

${ }^{48}$ See generally on these gaps, Erik Jaap Molenaar, 'Arctic Marine Shipping: Overview of the International Legal Framework, Gaps and Options’ (2008-2009) 18 Journal of Transnational Law and Policy 318.

${ }^{49}$ See Arctic Waters Pollution Prevention Act (R.S., 1985, c. A-12).

${ }^{50}$ The mandatory measures on safety are in part I-A of the Polar Code and those on pollution prevention in part II-A. Recommendatory provisions for both are found in parts I-B and II-B.

${ }^{51}$ http://www.imo.org/MediaCentre/HotTopics/polar/Pages/default.aspx
} 
being followed for the environmental measures. The IMO’s Marine Environment Protection Committee (MEPC) approved the amendments that were necessary to make the Code's environmental provisions mandatory under MARPOL, in October 2014 and it is anticipated that the Polar Code and associated MARPOL amendments will be adopted by the MEPC at its next session in May 2015. The expected date of entry into force of the Polar Code under both adoption procedures is 1 January 2017. Importantly, entry into force will be under the tacit acceptance $^{52}$ procedure of the IMO under which States are assumed to accept new amendments unless they take steps to indicate that they do not accept them. This process then will ease the entry into force of the Polar Code.

By the adoption of the Polar Code, improved mandatory standards are now established for future shipping in the Arctic, which is good news for the protection of the Arctic marine environment. This coupled with the various provisions relating to the increasing number of tourist vessels ${ }^{53}$ in the polar regions should go a long way towards protecting the Arctic Ocean and its biodiversity. Inevitably, however, there will be a need for further development of some of the measures as technology or experience associated with increased navigation in the Arctic point to gaps in coverage. There may also be a need to develop some of the issues not addressed in the code such as polar specific ballast water standards. Any further laws in relation to shipping will be developed through the IMO. If the EU is to influence the development of laws

\footnotetext{
${ }^{52}$ It means that the body which adopts the amendment to an annex by a majority vote, at the same time fixes the entry into force and the time period within which the contracting parties will have the opportunity to notify their rejection of the amendment, or to remain silent on the subject. A decision taken by a majority will be binding for states that did not support the decision, unless they explicitly opt out within the time period foreseen. In case of silence, the amendment is considered to have been accepted by the party.

${ }^{53}$ See Resolution A.999 (25) (2007) Guidelines on voyage planning for passenger ships operating in remote areas (London, 3 January 2008); Guidelines for Ships Operating in Polar Waters (IMO Resolution A.1024(26)); and the Enhanced Contingency Planning Guidance for Passenger Ships Operating in Areas Remote from SAR Facilities (MSC.1/Circ.1184).
} 
in this area it needs to be able to influence the IMO's work even though it is not a member of the IMO. In fact, this ought not to prove problematic for the EU as it has already influenced the international decision making process for preventing vessel source pollution in the past decade. $^{54}$

The European Commission, with the assistance of the European Maritime Safety Agency (EMSA), arranges meetings with EU Member States, prior to IMO sessions, in order to build a common EU position on EU relevant topics within the decision making process. ${ }^{55}$ In 2005 , the "Procedural framework for the adoption of Community or common positions for IMO related issues and rules governing their expression in the IMO” (SEC (2005) 449, Procedural Framework) was drafted by the Council. ${ }^{56}$ It was, in effect, confirmed in Case C-45/07 (Commission v. Greece), where the ECJ provided that: "The mere fact that the Community is not a member of an international organization ... does not prevent its external competence from being in fact exercised, in particular through the Member States acting jointly in the Community's interest." 57 The EU could also make use of this coordination process within the IMO to pursue its Arctic policy objectives. For example, the EU might consider proposing the establishment of special areas in particular areas, such as around Svalbard, to ensure zero discharge from ships sailing in the Svalbard fisheries protection zone. ${ }^{58}$

In addition, as an economic power and potential destination for trans-Arctic shipping, the EU could take action internally which could have a significant impact on Arctic shipping. It

\footnotetext{
${ }^{54}$ Liu \& Maes, n. 18 above.

${ }^{55}$ SWD (2012) 182 of 26 June 2012, 23.

${ }^{56}$ SEC (2005) 449 of 1 April 2005.

${ }^{57}$ ECJ, Case C-45/07, Commission v. Hellenic Republic, para. 30,31.

${ }^{58}$ See further Nengye Liu, 'The European Union's Potential Contribution to Enhanced Governance of Arctic Shipping' (2013)73 (4) Zeitschrift für ausländisches öffentliches Recht und Völkerrecht 732.
} 
could strengthen its port state control to address a number of issues such as a ban on the carriage and/or use of heavy grade fuels by trans-Arctic shipping. In fact, as illustrated by Bang, this is likely to be the most effective way to combat vessel-source pollution. ${ }^{59}$

Finally, the EU may take action as a flag State to enforce existing laws. For example, in order to combat invasive species from ballast water in the fragile Arctic marine ecosystem, the EU could implement the BWM Convention before its entry into force for EU flagged vessels. It has taken similar action previously, for example implementing the IMO Torremolinos International Convention for the Safety of Fishing Vessels (Torremolinos Convention, superseded by the 1993 Torremolinos Protocol; Cape Town Agreement of 2012 on the Implementation of Provisions of the 1993 Protocol $)^{60}$ for EU flagged vessels before its entry into force. ${ }^{61}$

\section{The EU and Arctic Fisheries}

While there is no possibility of fisheries within the central Arctic Ocean at present, ${ }^{62}$ commercial fishing activity does occur in the North Atlantic and North Pacific both in some

\footnotetext{
${ }^{59}$ Ho-sam Bang, 'Is Port State Control an Effective Means to Combat Vessel-Source Pollution? An Empirical Survey of the Practical Exercise by Port States of Their Powers of Control' (2008) 23 (4) International Journal of Marine and Coastal Law 717. For details about Port State Control, see Z. Oya Ozcayir, 'The Use of Port State Control in Maritime Industry and Application of the Paris MOU’ (2008-2009) 14 (2) Ocean and Coastal Law Journal 201-239.

${ }^{60}$ IMCO (092) F41; IMCO/SFV/CONF./8 \& Corr.1.

${ }^{61}$ Council Directive 97/70/EC of 11 December 1997 Setting up a Harmonised Safety Regime for Fishing Vessels of 24 Metres in Length and over, [1997] OJ L34/1.

62 PAME, The Arctic Ocean Review Project, Final Report, (Phase II 2011-2013), Kiruna May 2013, Protection of the Arctic Marine Environment (PAME) Secretariat, Akureyri (2013), 37.
} 
high seas areas, viz the Donut hole $\mathrm{e}^{63}$ and Loophole ${ }^{64}$ and within the exclusive economic zone of the Arctic coastal States. Climate change is likely to lead to an increase in fishing activity, both through the reduction in sea ice extent opening up new areas of the Arctic Ocean to fisheries, and through likely changes to the composition of fisheries making commercial fishing in areas already fished ever more profitable. As the Arctic Climate Impact Assessment noted: "a moderate warming will improve the conditions for some of the most important commercial fish stocks. This is most likely to be due to enhanced levels of primary and secondary production resulting from reduced sea-ice cover and more extensive habitat areas for subarctic species such as cod and herring”, ${ }^{65}$

The impact of current and future fisheries on the marine environment and marine biodiversity in the Arctic is not likely to be fundamentally different from impacts to the marine environment and biodiversity in other parts of the globe. ${ }^{66}$ Across the globe we see that marine capture fisheries are generally at or exceeding the limits of sustainable fisheries. The declining global marine catch over the last few years together with the increased percentage of overexploited fish stocks and the decreased proportion of non-fully exploited species around the world convey a strong message that the state of the world's marine fisheries is worsening and that this has had a negative impact on fishery production. ${ }^{67}$ This impact on fisheries production combined with the physical harm caused by the, often highly destructive, methods

\footnotetext{
631994 Convention on the Conservation and Management of Pollock Resources in the Central Bering Sea (1994) 34 I.L.M. 67 (the 'Donut Hole agreement')

${ }^{64}$ The Agreement Concerning Certain Aspects of Cooperation in the Area of Fisheries 1999 (Loophole Agreement) available at http://www.ecolex.org/server2.php/libcat/docs/TRE/Full/Other/TRE-149526.htm

${ }^{65}$ Arctic Climate Impact Assessment, n. 9 above.

${ }^{66}$ Erik Jaap Molenaar, 'Arctic Fisheries Conservation and Management: Initial Steps of Reform of the International Legal Framework' (2009)1 Yearbook of Polar Law 433.

${ }^{67}$ The State of World Fisheries and Aquaculture, FAO, Rome, 2012, 12.
} 
used for fishing, has, in many parts of the world, had a severe impact on the marine ecosystem and it is likely it will have the same types of impacts in the Arctic. For example, bottom trawling damages coral reefs and seamounts; ${ }^{68}$ nylon driftnets float like a curtain and when lost at sea can trap a variety of species. ${ }^{69}$ Moreover, overfishing has been identified as a major source of biodiversity loss. ${ }^{70}$ Discards, fish thrown away because they are the wrong type, or wrong size of fish or because quotas have been exceeded, add a growing element of pointless waste to the overfishing of many traditionally rich fishing grounds. ${ }^{71}$

A range of global legally binding and non-legally binding fisheries instruments are applicable in the marine Arctic which may provide a framework to address these problems if and when they occur there too. These instruments include UNCLOS; the Fish Stocks Agreement; ${ }^{72}$ the Compliance Agreement; ${ }^{73}$ the Port State Measures Agreement; ${ }^{74}$ other FAO

\footnotetext{
68 See, for example, Callum Roberts “Ocean of Life” Penguin, 2013 at, for example p. 44.

${ }^{69}$ United Nations General Assembly Resolution on Large-scale Pelagic Driftnet Fishing and its Impact on the Living Marine Resources of the World's Oceans And Seas. A/RES/44/225, 1989.

${ }^{70}$ S. M. Garcia et al., 'The Ecosystem Approach to Fisheries. Issues, Terminology, Principles, Institutional Foundations, Implementation and Outlook’, FAO Fisheries Technical Paper. No. 433. Rome, FAO. 2003, 9-12.

${ }^{71}$ See, for example, Ben Diamond and Bryce D. Beukers-Stewart, 'Fisheries Discards in the North Sea: Waste of Resources or a Necessary Evil?’ (2011) 19 (3) Reviews in Fisheries Science 231 and Kieran Kelleher, Discards in the World’s Marine Fisheries: An Update, FAO Fisheries Technical Paper 470 (2005).

${ }^{72}$ United Nations Conference on Straddling Fish Stocks and Highly Migratory Fish Stocks: Agreement for the Implementation of the Provisions of the United Nations Convention of the Law of the Sea of 10 December 1982, Relating to the Conservation and Management of Straddling Fish Stocks and Highly Migratory Fish Stocks, (1995) 34 (6) ILM 1542-1580.

${ }^{73}$ The Agreement to Promote Compliance with International Conservation and Management Measures by Fishing Vessels on the High Seas (Rome, 24 November 1993; in force 24 April 2003).

${ }^{74}$ Agreement on Port State measures to prevent, deter, and eliminate Illegal, Unreported and Unregulated fishing (Rome, 22 November 2009; not yet in force).
} 
fisheries instruments, most importantly, the FAO Code of Conduct for Responsible Fisheries, ${ }^{75}$ including its Technical Guidelines and international plans of action, ${ }^{76}$ the International Guidelines on Deep-sea Fisheries in the High Seas, ${ }^{77}$ and the International Guidelines on Bycatch Management and Reduction of Discards; ${ }^{78}$ and certain (parts of) United Nations General Assembly (UNGA) Resolutions, ${ }^{79}$ which have contributed to the phase-out of largescale pelagic driftnet fishing and imposed innovative restrictions on bottom-fisheries on the high seas. Both initiatives were predominantly aimed at the conservation of non-target species and vulnerable marine ecosystems. ${ }^{80}$ There are, however, several major gaps in the existing regime of international fisheries fora and instruments. Some of these gaps affect fisheries globally others are Arctic specific. For example, a lack of data dogs fisheries management across the globe, but is likely to be particularly problematic in the Arctic, particularly in areas that have been covered by ice and in which relatively little is known about the native species or their interactions. The Food and Agriculture Organization (FAO), for example, estimates that

Only 10 percent of the exploited fish stocks are assessed, but not always regularly. Although these assessed stocks include the largest single-species

\footnotetext{
${ }^{75}$ Adopted by the Twenty-eighth Session of the FAO Conference on 31 October 1995. available from the Food and Agriculture Organisation Fisheries home page http://www.fao.org/fi/defaultN.asp

76 See, for example, FAO “The International Plan of Action to Prevent, Deter and Eliminate Illegal, Unreported and Unregulated Fishing” (Rome, 2001)

${ }^{77}$ FAO International Guidelines on Deep-sea Fisheries in the High Seas (Rome, 2009).

${ }^{78}$ International Guidelines on Bycatch Management and Reduction of Discards (Rome. 2011).

${ }^{79}$ UNGA Res. 46/215 (1991) and UNGA Res. 61/105 (2006), paras 80-89.

${ }^{80}$ For content of these global instruments see Erik Jaap Molenaar, 'Status and Reform of International Arctic Fisheries Law', in: Elizabeth Tedsen, Sandra Cavalieri and R. Andreas Kraemer (eds.), Arctic Marine Governance, Opportunities for Transatlantic Cooperation (Springer, 2014), 103, at 108-110.
} 
stocks and account for almost 80 percent of the total declared landings, it is clear that for the large majority of the exploited fish stocks there is no or little information on their status. ${ }^{81}$

This lack of data impinges upon the management approaches that can be used. Without information, it is difficult to know which approaches will work, either for the purposes of fisheries management or to minimize the impact on biodiversity more generally. Similarly, while UNCLOS and the Fish Stocks Agreement apply to the Arctic as a whole, there is, or will be a need for more Regional Fisheries Management Organizations (RFMOs) or Arrangements in the Arctic, particularly in the high seas area of the Arctic Ocean as it becomes ice free. ${ }^{82}$ Such bodies would add to the existing Loophole and Donut hole agreements and to existing RFMOs - the Northwest Atlantic Fisheries Organization (NAFO), the North Atlantic Salmon Conservation Organization (NASCO) and the North East Atlantic Fisheries Commission (NEAFC). ${ }^{83}$ There will likely also be the need for specific measures similar, for example, to the moratorium on fishing in the Arctic peanut hole. ${ }^{84}$

These pressures and opportunities give rise again then to the question of what the EU can

\footnotetext{
${ }^{81}$ FAO, The State of World Fisheries and Aquaculture 2010 (2010) at 40. See also, for example, EC Commission, Staff Working Paper on Impact Assessment, accompanying the document EC Commission, Proposal for a Regulation of the European Parliament and of the Council on the Common Fisheries Policy [repealing EC Regulation 2371/2002], Doc. SEC (2011) 891 (final) at 13, where it is noted that 'reliable scientific advice exists for around 30\% of all EU stocks.'

82 Erik Jaap Molenaar, 'Arctic Fisheries Management', in: Erik Jaap Molenaar, Alex Oude Elferink and Donald Rothwell (eds), The Law of the Sea and the Polar Regions, Interactions between Global and Regional Regime (Martinus Nijhoff, Netherlands, 2013) 260-261.

${ }^{83}$ Arctic Ocean Review, n 62 above, 39.

${ }^{84}$ See, Alex G Oude Elferink 'The Sea of Okhotsk Peanut Hole De facto Extension of Coastal State Control’ in: Olav Schram Stokke Governing High Seas Fisheries: The Interplay of Global and Regional Regimes (Oxford University Press, Oxford, 2001)
} 
do to minimize the impacts of fisheries on Arctic marine biodiversity. The EU accounts for 6 per cent of total fisheries production worldwide. ${ }^{85}$ One might anticipate, therefore, that it would play a significant role in fisheries in the Arctic too particularly as new fisheries arise. As a significant global player, the EU could play an active role in the development of new RFMOs, and could join existing RFMOs, using its position to strengthen their provisions. It has already used its external competence regarding fisheries to negotiate and conclude conventions with third states based on the ERTA/AETR principle ${ }^{86}$ and is party to NEAFC on that basis.

The EU could also use its position in global fisheries to support existing proposals for improved management. For example, the U.S. has adopted a closure of commercial fishing in its waters north of the Bering Strait until there is appropriate scientific understanding and management in place. ${ }^{87}$ The moratorium prohibits commercial fishing in all marine areas in the U.S. EEZ of the Chukchi and Beaufort seas. ${ }^{88}$ The U.S. is also proposing an agreement "that would close the international waters of the Arctic Ocean to commercial fishing until there is a good scientific foundation on which to base management of any potential fishing." ${ }^{89}$ The EU could use its position in global fisheries to support this proposal. Particularly as the EU itself has been advocating a precautionary approach whereby, prior to the exploitation of any new fishing opportunities, a regulatory framework for the conservation and management of fish stocks should be established for those parts of the Arctic high seas not yet covered by an

\footnotetext{
${ }^{85}$ Facts and Figures on the Common Fisheries Policy, Basic Statistical Data, 2012, 19.

${ }^{86}$ ECJ, Case C-22/70, Commission v. Council, [1971] ECR.263, Para.19.

${ }^{87}$ Arctic Ocean Review n 62 above, 39

${ }^{88}$ Fishery Management Plan for Fish Resources of the Arctic Management Area, North Pacific Fishery Management Council, Alaska, 2009.

${ }^{89}$ With Ice Melting, U.S. Pushes for Limits on Fishing in Arctic Ocean, http://www.latimes.com/nation/nationnow/la-na-nnarctic-ocean-fishing-20140222-story.html\#axzz2uG7uwsEm.
} 
international conservation and management system. ${ }^{90}$ Such action is likely to be fruitful. Senior officials of the five coastal states surrounding the central Arctic Ocean - Canada, Denmark (Greenland), Norway, the Russian Federation and the United States had a meeting on 24-26 February 2014 in Nuuk, Greenland. The participants of Nuuk Meeting recognized the need for and agreed to work towards interim precautionary measures for the central Arctic Ocean to prevent any future commercial fisheries without the prior establishment of appropriate regulatory mechanisms. ${ }^{91}$

In this context, it is also worth noting changes in the Common Fisheries Policy (CFP) effective from 1 January 2014, such as the discard ban ${ }^{92}$ by which "the CFP shall gradually eliminate discards, on a case-by-case basis, taking into account the best available scientific advice, by avoiding and reducing, as far as possible, unwanted catches, and by gradually ensuring that catches are landed". ${ }^{93}$ This obligation ("the landing obligation") is applicable to all catches of species, which are subject to catch limits made during fishing activities in EU waters or by EU fishing vessels. ${ }^{94}$ This means fishing vessels of EU Member States operating in the Arctic must also follow this obligation. It is possible that the EU could use its position as the owner of a globally significant fishing fleet to promote the adoption of similar measures amongst other fleets, if, for example, the EU fleet can demonstrate improved profitability as a

\footnotetext{
90 JOIN (2012) 19, 10.

${ }^{91}$ Consensus among the 5 Arctic Coastal States to Protect the Central Arctic Ocean against Unregulated Fishery, Government of Greenland, 28 Feb 2014, http://naalakkersuisut.gl/en/Naalakkersuisut/Press-Statements/2014/02/Arktisk-hoejsoefiskeri.

92 See Elizabeth A. Kirk, 'Marine Governance, Adaptation, and Legitimacy' (2011) 22 Yearbook of International Environmental Law 134-137.

${ }^{93}$ Regulation (EU) 1380/2013 of 11 December 2013 on the Common Fisheries Policy, amending Council Regulation (EC) 1954/2003 and (EC) 1224/2009 and repealing Council Regulations (EC) 2371/2002 and (EC) 639/2004 and Council Decision 2004/585/EC, [2013] OJ L 354/22, Article 5 (a).

${ }^{94}$ Regulation 1380/2013, Preamble, para. 26.
} 
result of this new approach. Similarly the adoption of measures such as the discards ban enhances the credibility of the EU as a promoter of similar measures at the global level, through regional RFMOs or the coming interim measures for central Arctic Ocean fisheries. Once again such a move is likely to find some support in the Arctic. Norway, for example, has already experienced the benefits of a discards ban. ${ }^{95}$

Moreover, as one third of fish caught in the Arctic are sold on the European market, ${ }^{96}$ the EU also has power to use internal actions that might create external impacts on sustainable fisheries in the Arctic, such as port state control measures. Such measures are expressly permitted under Article 23 of the Fish Stocks Agreement in relation to straddling and highly migratory stocks (categories which will capture many of the commercially valuable Arctic stocks) to promote "the effectiveness of subregional, regional and global conservation and management measures”. In the authors' opinion, the import ban imposed by the EU on AtlantoScandian herring and Northeast Atlantic mackerel caught under the control of the Faroe Islands, is a perfect example. ${ }^{97}$ Although problematic in that the measures adopted may have been discriminatory and therefore not in compliance with either trade law (a dispute between the EU and Faroe Islands was before the WTO $)^{98}$ or the Fish Stocks Agreement, ${ }^{99}$ this may provide an example of possible routes to action for the EU. The EU Faroe Islands dispute was solved by

\footnotetext{
${ }^{95}$ Ben Diamond and Bryce D. Beukers-Stewart, 'Fisheries Discards in the North Sea: Waste of Resources or a Necessary Evil?’ (2011) 19 (3) Reviews in Fisheries Science 231.

96 JOIN (2012) 19 supra n.2, 10.

${ }^{97}$ Regulation (EU) 1026/2012 of 25 October 2012 on Certain Measures for the Purpose of the Conservation of Fish Stocks in relation to Countries Allowing Non-Sustainable Fishing, [2012] OJ L316/34.

98 Yoshimichi Ishikawa, 'The EU-Faroe Islands Herring Stock Dispute at the WTO: the Environmental Justification’ (2014) 18 (4) ASIL Insights.

${ }^{99}$ Article 23, Fish Stocks Agreement.
} 
a political understanding, ${ }^{100}$ which included an agreement by the Faroe Isles to end their unsustainable herring fishing practices. While this may not have met all of the EU's demands or desires with regard to all the fisheries in question, it does demonstrate that the use of port restrictions can have some impact. If, in future the EU can ensure that it applies the measures in a non-discriminatory way then, as with shipping, the use of port State measures is likely to prove successful in influencing action to protect Arctic marine biodiversity from harm. Indeed, given that it does not rely on the ability of the EU to persuade other actors to join its action or share its views, port State action may well prove to be a more fruitful course of action than any of the other options considered here.

\section{The EU and Arctic Offshore Oil and Gas Operations}

The Arctic contains vast oil and natural gas reserves - the U.S. Geological Survey estimates the Arctic could contain 1,670 trillion cubic feet (tcf) of natural gas and 90 billion barrels of oil, or 30 per cent of the world's undiscovered gas and 13 per cent of oil. ${ }^{101}$ Climate change is gradually making access to the Arctic marine area easier, and as such, offshore hydrocarbon exploitation is anticipated to be a major future economic activity in the Arctic. ${ }^{102}$ As long as the world economy is dependent on oil and gas, the extraction of oil and gas in the Arctic seems

\footnotetext{
${ }^{100}$ Herring Dispute between European Union and Faroe Islands nears end, European Commission Press Releas, 11 June 2014, http://europa.eu/rapid/press-release_IP-14-668_en.htm.

${ }^{101}$ Circum-Arctic Resource Appraisal: Estimates of Undiscovered Oil and Gas North of the Arctic Circle, Fact Sheet 20083049, United States Geological Survey (USGS), United States.

102 Kamrul Hossain, Timo Koivurova and Gerald Zojer, 'Understanding Risks Associated with Offshore Hydrocarbon Development', in Elizabeth Tedsen, Sandra Cavalieri and R. Andreas Kraemer (eds), Arctic Marine Governance, Opportunities for Transatlantic Cooperation (Springer, Germany, 2014) 159, 160. See also Yusuf Mohammad Yusuf, 'The Environmental Problems Associated with Offshore Oil and Gas Activities’ (2014) 12 (1) Oil, Gas \& Energy Law 1-16.
} 
to be unavoidable. As demonstrated by the 'Deepwater Horizon' disaster in the Gulf of Mexico, ${ }^{103}$ however, there are significant risks associated with offshore oil and gas activities in a fragile marine ecosystem. The release of oil through accidents or operations of offshore platforms could cause significant damage to the Arctic marine ecosystem: for example, spills from accidental blow outs at the well, or accidents involving tankers transporting oil/gas; operational pollution from offshore installations, harbours and from oil tankers; accidental releases from storage or during offloading; or discharges from pipelines. ${ }^{104}$ As mentioned earlier, any oil pollution can prove particularly problematic in the Arctic, where dispersal rates and natural clean up rates are slower than in other areas of the world and where access to attend to accidents may prove highly problematic. ${ }^{105}$ Similarly Arctic species may prove particularly vulnerable to the noise pollution that attends these activities. Absent the noise of the movement of the Arctic icepack, the Arctic marine environment is the quietest in the world. The species living there may then be particularly sensitive to underwater noise, interfering, for example, with their navigational systems. ${ }^{106}$ Similarly the construction of oil and gas installations may have other significant impacts on the habitat of some biodiversity, particularly given the nature

\footnotetext{
${ }^{103}$ See Report of Investigation into the Circumstances Surrounding the Explosion, Fire, Sinking and Loss of Eleven Crew Members aboard the Mobile Offshore Drilling Unit Deepwater Horizon in the Gulf of Mexico, April 20-22, 2010, United States Coast Guard, 2011.

${ }^{104}$ Arctic Guide (updated document of December 31, 2008) - Information on emergency systems and contact points, overview of environmental risks, and applicable agreements, EPPR, Arctic Council.

105 See, for example, Committee on Responding to Oil Spills in the U.S. Arctic Marine Environment, Ocean Studies Board, Division of Earth and Life Studies, Polar Research Board, Division of Earth and Life Studies, Marine Board, Transportation Research Board, National Research Council of the National Academies Responding to Oil Spills in the US Arctic Marine Environment (National Academies Press, 2014)

${ }^{106}$ See, Sue E. Moore, Randall R. Reeves, Brandon L. Southall, Timothy J. Ragen, Robert S. Suydam, and Christopher W. Clark, “A New Framework for Assessing the Effects of Anthropogenic Sound on Marine Mammals in a Rapidly Changing Arctic” (2012) 62 (3) BioScience 289-295.
} 
of Arctic installations - the presence of ice may, for example lead to the need to construct artificial islands of gravel and sediment ${ }^{107}$ which may impinge on traditional migration routes, or cause problems due to changes in sediment mobility et cetera.

Once again, there are a number of global regimes that provide some regulation of these activities - UNCLOS, MARPOL 73/38, the 1990 International Convention on Oil Pollution Preparedness, Response and Cooperation (OPRC) ${ }^{108}$ and the 1972 Convention on the Prevention of Marine Pollution by Dumping of Wastes and Other Matters (London Convention) and its 1996 Protocol. ${ }^{109}$ And once again these agreements do not provide a comprehensive regulatory regime for the Arctic. ${ }^{110}$ There are many gaps, for example the regulation on the construction of artificial islands is somewhat limited, as is the international regulation of noise pollution. ${ }^{111}$ As with shipping, specific standards are likely to be required in the Arctic to protect it from the dangers posed by extractive industries.

To some extent Arctic specific standards do exist. The Convention for the Protection of the Marine Environment of the North-East Atlantic (OSPAR) ${ }^{112}$ deals with prevention and elimination of pollution from offshore sources in Annex III and its range extends throughout the North-East Atlantic. It is concerned with the prevention and elimination of pollutants as well as ensuring sustainable use of the sea. ${ }^{113}$ However, OSPAR only covers part of the Arctic

\footnotetext{
107 See, for example, the Endicott Development in US waters which sits partially on an artificial island.

${ }^{108}$ International Convention on Oil Pollution Preparedness, Response and Cooperation, (1991) 30 (3) ILM 733-761.

${ }^{109}$ Convention on the Prevention of Marine Pollution by Dumping of Wastes and Other Matters, (1972) 11 (6) ILM 12911314; 1996 Protocol, (1997) 36 (1) ILM 1-30.

${ }^{110}$ Arctic Ocean Review, n. 62 above, 57.

${ }^{111}$ Karen N. Scott, “International Regulation of Undersea Noise” (2004) 53 ICLQ 287.

${ }^{112}$ Convention for the Protection of the Marine Environment of the North-East Atlantic, (1993) 32 (4) ILM 1069-1100.

113 Johnsen, K. I., Alfthan, B., Hislop, L., Skaalvik, J., (eds), 2010. Protecting Arctic Biodiversity, United Nations Environment Programme, GRID-Arendal, 26.
} 
Ocean. ${ }^{114}$ Similarly two instruments have been adopted that specifically address offshore oil and gas extraction in the Arctic. Firstly the Arctic Offshore Oil and Gas Guidelines ${ }^{115}$ propose a non-binding set of suggested best practices for oil and gas extraction designed to advise industry officials and government regulators. ${ }^{116}$ Secondly, the Agreement on Cooperation on Marine Oil Pollution, Preparedness and Response in the Arctic ${ }^{117}$ was adopted under the auspices of the Arctic Council in 2013 (though it has yet to enter into force).

This scenario provides a similar opportunity for the EU to those described in relation to both shipping and fisheries. The EU indeed has no territorial jurisdiction on offshore oil and gas operations in national waters of Arctic States. However, as a major consumer, importer and technology provider of energy and raw materials, the EU is becoming an emerging actor in global energy politics ${ }^{118}$ and it is one with an interest in the resource policy development in the Arctic states. ${ }^{119}$ It appears, therefore, to be in a position to help promote some existing proposals. The question here is what exactly should the EU promote? An international legallybinding agreement or an Arctic-specific legally binding agreement? For example, the Global

\footnotetext{
${ }^{114}$ Region I - Arctic Waters, http://www.ospar.org/content/content.asp?menu=00420211000000_000000_000000.

${ }^{115}$ Arctic Council, Protection of the Arctic Marine Environment Working Group, Arctic Offshore Oil and Gas Guidelines, April 292009.

${ }^{116}$ Emily Hildreth, 'Holes in the Ice: Why a Comprehensive Treaty will not Succeed in the Arctic and How to Implement an Alternative Approach’ (2011) 3 Yearbook of Polar Law 556.

${ }^{117}$ Agreement on Cooperation on Marine Oil Pollution, Preparedness and Response in the Arctic (Kiruna, 15 May 2013; not yet in force).

${ }^{118}$ Iana Dryer and Gerald Stang, ‘Energy Moves and Power Shifts: EU Foreign Policy and Global Energy Security’ ISSUE Report No 18, February 2014, 11.

119 JOIN (2012) 19, supra n.2, 9.
} 
Ocean Commission, ${ }^{120}$ in its Rescue Package for the Global Ocean, proposes the adoption of and improvement of international safety and environmental standards for offshore drilling on the continental shelf, including regional protocols to establish and implement such standards, with provisions for response-preparedness and capacity building in developing countries. ${ }^{121} \mathrm{~A}$ similar proposal has been initiated by the Indonesian Government after the 2009 Montara Oil Spill in the Timor Sea, off the northern coast of Western Australia. ${ }^{122}$ Given the fact that so far there are no universally agreed international standards for offshore drilling on the continental shelf, an international agreement would provide industry with a standard to meet, regardless of where in the world it was drilling. ${ }^{123}$ However, even if an international convention on offshore drilling could be adopted in the foreseeable future, it may not be that meaningful for the Arctic. A global convention has to allow for compromises between different interests from around the world; as such it may not be able to pay too much attention to the Arctic. It is therefore suggested that the EU should make efforts to promote an Arctic-specific legally binding agreement on offshore oil and gas operations, containing the highest safety standards. As noted earlier, non-binding Arctic Offshore Oil and Gas Guidelines have already been published by the PAME of the Arctic Council. These Guidelines could possibly become a starting point, or the basis for proposals from the EU.

The EU is aware of the fact that existing legislation and industry practices within the EU

\footnotetext{
${ }^{120}$ The Global Ocean Commission is a NGO originated as an initiative of The Pew Charitable Trusts, in partnership with Somerville College at the University of Oxford, Adessium Foundation and Oceans 5.

${ }^{121}$ From Decline to Recovery, a Rescue Package for the Global Ocean, Global Ocean Commission (2014), 64.

122 The European Commission was approached by Indonesian Government to support the initiative. The Commission however was not that interested in the proposal. Interview with representative of the DG Energy, European Commission, 9 September 2014, Brussels, Belgium.

${ }^{123}$ Rescue Package for the Global Ocean n. 121 above, 67.
} 
are diverse and fragmented. ${ }^{124}$ Directive 2013/30/EU notes that:

"the existing divergent and fragmented regulatory framework applying to safety of offshore oil and gas operations in the Union and current industry safety practices do not provide a fully adequate assurance that the risk of offshore accidents is minimised throughout the Union, and that in the event of an accident occurring in offshore waters of Member States, the most effective response would be deployed in a timely manner”. ${ }^{125}$

While the lack of an EU/Arctic coastline minimises the potential impact of any EU efforts to address these weaknesses, the establishment of minimum requirements for preventing major accidents and limiting the consequences of such accidents within the $\mathrm{EU}^{126}$ could be used as a model for similar Arctic requirements through the Arctic Council.

These proposals also raise the question of how the EU can act within the Arctic Council when it is not a member of that organization, nor even an observer. (The EU's application to become an observer of the Arctic Council was deferred in the Eighth Ministerial Meeting of the Arctic Council due to political differences.) ${ }^{127}$ As discussed in relation to shipping, the EU has successfully influenced decision-making processes within the IMO for decades through its coordination process, bringing together EU Member States to act with one voice in that organization. A number of EU Member States are also members, or observers of the Arctic Council: Denmark, Sweden and Finland are members and France, Germany, Netherlands,

\footnotetext{
${ }^{124}$ European Commission Communication of 27 October 2011 on Safety of Offshore Oil and Gas Prospection, Exploration and Production Activities, COM (2011) 688, 2.

${ }^{125}$ Directive 2013/30/EU of 12 June 2013 on Safety of Offshore Oil and Gas Operations and Amending Directive 2004/35/EC, [2013] OJ L178/66, Preamble.

${ }^{126}$ Directive 2013/30/EU, Art 1.

${ }^{127}$ Kiruna Declaration on the Occasion of the Eighth Ministerial Meeting of the Arctic Council, MM08-15 May 2013-Kiruna, Sweden, 6.
} 
Poland, Spain, the United Kingdom and Italy are all observers, giving the EU an opportunity to take a similar coordinated approach within the Arctic Council.

An alternative route is to take internal action within the EU and indeed this process has already started. EU Directive 2013/30/EU provides that "Member States shall require companies registered in their territory and conducting, themselves or through subsidiaries, offshore oil and gas operations outside the Union as licence holders or operators to report to them, on request, the circumstances of any major accident in which they have been involved”. ${ }^{128}$ Therefore, oil giants like British Petroleum (BP) and Shell, whose headquarters are based in EU Member States have to follow Directive 2013/30/EU even for activities in the Arctic. The high cost of doing business in the Arctic suggests that only the world's largest oil and gas companies may have the financial, technical, and managerial strength to meet the costs and long lead-times for projects that are dictated by challenging Arctic conditions. ${ }^{129}$ Thus having this type of control over companies such as BP and Shell is a significant initial step to improving the safety of offshore drilling in the Arctic. It will go some way to ensuring that big oil companies based in the EU think long and hard before they embark on a risky adventure in the Arctic. ${ }^{130}$ It also provides those companies with an incentive to support international agreements on Arctic offshore activities, support which could prove crucial to the EU's success in promoting any other agreements. ${ }^{131}$

\footnotetext{
${ }^{128}$ Directive 2013/30/EU, Article 20 (1).

${ }^{129}$ Nong Hong, 'The Energy Factor in the Arctic Dispute: A Pathway to Conflict or Cooperation?', (2012) 5 (1) Journal of World Energy Law and Business 13.

${ }^{130}$ Europe to Get its First EU-wide Offshore Oil and Gas Law, http://www.euractiv.com/energy/europe-get-eu-wide-offshoreoil-news-518002.

${ }^{131}$ On the role of industry in supporting or undermining developments in marine governance see Kirk n. 92 above.
} 


\section{Cross Sector Actions}

The routes to EU influence that have been discussed so far have focused on sector specific activities. These sectors were chosen as the starting point for the discussion in part because it was relatively easy to show the EU's interest in two of them - fishing and shipping - and to show the possible routes to action regardless of the EU's status as a recognized Arctic actor or otherwise in all of them. In this last section we consider actions that cut across sectors, specifically the adoption of ecosystem-based management approaches and the establishment of marine protected areas (MPAs). Here, the ability of the EU to act may depend a little more on being able to prove its interests in the Arctic. It has no Member States with Arctic coastlines, but the interests it has in fisheries, in particular in relation to high seas fisheries, and shipping and the offshore extractive industries in the Arctic discussed above, together with its commitment to protect biological diversity point to good reason for it to act under the framework of the CBD.

Motivation for cross-sector action comes from the fact that the complexity inherent in the marine environment, with its high biophysical dynamics, biological diversity and ecological interaction, combined with the common pool characteristics of marine resources, point to the need for an integrated approach to management to be taken. ${ }^{132}$ The European Commission has already proposed the exploration of "the possibility of establishing new, multi-sector frameworks for integrated ecosystem management. ${ }^{133}$ One such possibility is to build upon the ecosystem approach, which is already partially recognized within the laws on marine

\footnotetext{
${ }^{132}$ Arctic Ocean Review n 62 above, 75.

${ }^{133}$ COM (2008) 763, 11.
} 
governance. $^{134}$

At present the key measures on the ecosystem approach are those adopted by the Conference of Parties (COP) of the CBD. ${ }^{135}$ The COP decisions address the application of the ecosystem approach in general, not just in the marine environment. For example, COP5 endorsed the description of the ecosystem approach and operational guidance and recommended the application of the principles and other guidance on the Ecosystem Approach (EA). There is therefore scope to develop provisions focusing on the marine environment. In some senses the chances of EU success in this area appear quite high. The need for oceans management based on an ecosystem approach is now widely recognized by the international community, as reflected in calls for the application of the ecosystem approach by 2010 in the 2002 Johannesburg Plan of Implementation of the World Summit on Sustainable Development (WSSD) ${ }^{136}$ as well as in recommendations from the UN General Assembly. ${ }^{137}$ Its application in the Arctic was also specifically recognized by the Arctic Council in the 2004 Arctic Marine Strategic Plan, which states that ecosystem-based management (EBM) is the best approach to managing the Arctic marine environment. ${ }^{138}$ (The definition it provides of the EBM is very

\footnotetext{
${ }^{134}$ Elizabeth A. Kirk ' The ecosystem approach and the search for an objective and content for the concept of holistic ocean governance' forthcoming (2015) 46 Ocean Development and International Law.

${ }^{135}$ COP 5 Decision V/6; COP 6 Decision VI/12; COP 7 Decision VII/11; COP 9 Decision IX/7.

${ }^{136}$ A/CONF.199/20.

${ }^{137}$ Alf H. Hoel (ed.), Best Practices in Ecosystem-based Ocean Management (Bepomar) Final Report, Sustainable Development Working Group, Arctic Council (2009), 8. See UNGA Resolution 60/30, Resolution 61/222 and Resolution $62 / 177$.

${ }^{138}$ Arctic Marine Strategic Plan, Protection of the Arctic Marine Environment (PAME) Working Group, Arctic Council (2004), 
similar to the definition of the ecosystem approach under the CBD. $)^{139}$

The Protection of the Arctic Marine Environment (PAME) Working Group of the Arctic Council established an Ecosystem Approach expert group (EA-EG) in 2007. However, in the Arctic as elsewhere, implementation of the EBM/EA is not fully developed. While all Arctic countries either are undertaking or have undertaken work regarding EBM, and several have implemented or are in the process of implementing EBM/EA in sea areas under national jurisdiction in one form or another, ${ }^{140}$ implementation is far from perfect. Even in a small developed country like Norway with a compact, centralized decision-making system in ocean affairs, the system that has been developed is described as "pragmatic sector-based coordination, rather than fully integrated management”. ${ }^{141}$ This in contrast to the recommendation by the Arctic Biodiversity Assessment that a comprehensive and integrated approach is needed to address the interconnected and complex challenges facing biodiversity and to ensure informed policy decisions in a changing Arctic. ${ }^{142}$

How then could the EU take forward the application of the ecosystem approach in the Arctic? The EU could conduct more scientific research in the Arctic, both from ships and from shore under arrangements with coastal States. The EU could also help fund Arctic Council projects of interest once it is granted observer status. It could pursue further agreement within the Arctic Council using the coordination process referred to earlier in the paper. It is, however,

\footnotetext{
${ }^{139}$ Susanah Stoessel, Elizabeth Tedsen, Sandra Cavalieri and Arne Riedel, 'Environmental Governance in the Marine Arctic’, in: Elizabeth Tedsen, Sandra Cavalieri and Andreas Kraemer (eds.), Arctic Marine Governance, Opportunities for Transatlantic Cooperation (Springer, Germany, 2014) 48.

${ }^{140}$ See Alf H. Hoel, n 137 above.

${ }^{141}$ Alf H. Hoel, 'Integrated Oceans Management in the Arctic: Norway and Beyond’ (2010) 1 (2) Arctic Review on Law and Politics 205.

${ }^{142}$ Conservation of Arctic Flora and Fauna (CAFF). 2013. Arctic Biodiversity Assessment: Report for Policy Makers. CAFF, Akureyri, Iceland, 17.
} 
worth recalling once again that the Arctic Council is a "soft law organization". As such the EU may wish to pursue action that is more likely to lead to a binding agreement.

As a party to the CBD under the so-called "regional economic integration organizations" (REIO) clause, ${ }^{143}$ the EU could pursue the adoption of further measures there, particularly measures focused on the application of the ecosystem approach to the marine environment, though it may be harder to obtain Arctic specific measures on the use of the ecosystem approach within the CBD.

In addition to pursuing the development of the application of the ecosystem approach, the EU could potentially address the adoption of marine protected areas in the Arctic. Protected areas have been described by the CBD as an important means to achieve conservation gains. ${ }^{144}$ In 2014, The European Parliament indicated support for the development of a network of Arctic conservation areas and, in particular, the protection of the international sea area around the North Pole outside the economic zones of the coastal states. ${ }^{145}$ However, to date, there is no legal regime that provides for cross-sector marine protected areas on the high seas. ${ }^{146}$ Although the OSPAR Commission has established 8 high sea MPAs in the North-east Atlantic, these cannot regulate activities of non-contracting parties. Moreover, so far OSPAR does not have a clear management plan for its high sea MPAs. ${ }^{147}$ The provisions of the CBD in relation to

\footnotetext{
${ }^{143}$ CBD, Article 34 (1).

${ }^{144}$ Mark D. Spalding, Imèn Meliane, Amy Milam, Claire Fitzgerald and Lynne Z. Hale, 'Protecting Marine Spaces: Global Targets and Changing Approaches’ (2013) 27 Ocean Yearbook 214.

${ }^{145}$ European Parliament Resolution of 12 March 2014 on the EU Strategy for the Arctic (2013/2595(RSP), 345.

${ }^{146}$ Ingvild Ulrikke Jakobsen, 'Marine Protected Areas as Tool to Ensure Environmental Protection of the Marine Arctic: Legal Aspects', in: Elizabeth Tedsen, Sandra Cavalieri and Andreas Kraemer (eds.), Arctic Marine Governance, Opportunities for Transatlantic Cooperation (Springer, Germany, 2014) 220.

${ }^{147}$ Interview with representatives from the Secretariat of OSPAR Commission, London, UK, 19 Oct 2014.
} 
protected areas apply, or at least appear to apply within State jurisdiction only. ${ }^{148}$ The most obvious regime to consider as an alternative to the CBD is, of course, UNCLOS. There is, however, a potential problem with relying upon UNCLOS. It makes no reference to biodiversity, especially in areas beyond national jurisdiction, though Art.194 (5) does require parties to take measures necessary 'to protect and preserve rare or fragile ecosystems as well as the habitat of depleted, threatened or endangered species and other forms of marine life', ${ }^{149}$ providing an inroad for action. The lack of a regime addressing biodiversity in areas beyond national jurisdiction has already been identified by the international community and, during the UN Conference on Sustainable Development (Rio+20), states committed, on an urgent basis, to addressing the issue. The agreement to act included a commitment to taking a decision on the development of an international instrument under UNCLOS, before the end of the sixtyninth session of the UN General Assembly to address biodiversity in areas beyond national jurisdiction. ${ }^{150}$ It is worth noting that the working group that led to this initiative specifically recommended that the process to establish a legal framework include within its discussion measures such as area-based management tools, including marine protected areas. ${ }^{151}$

The EU, as a contracting party of UNCLOS, has been a strong supporter of the

\footnotetext{
${ }^{148}$ CBD, Article 8.

${ }^{149}$ Patricia W. Birnie, Alan E. Boyle and Catherine Redgwell, International Law \& the Environment, 3rd edn. (Oxford University Press, UK, 2009) 745.

${ }^{150}$ Resolution adopted by the General Assembly on 27 July 2012, The Future We Want (UN Doc. A/RES/66/288, 11 September 2012), para.162.

${ }^{151}$ Recommendations of the Ad Hoc Open-ended Informal Working Group to study issues relating to the conservation and sustainable use of marine biological diversity beyond areas of national jurisdiction and CoChairs’ summary of discussions, UNGA Doc A/66/119 Annex para 1.
} 
development of a new implementing agreement under UNCLOS on this topic. ${ }^{152}$ If the new implementing protocol can be adopted in the foreseeable future, it will provide a solid legal basis for the establishment of marine protected areas in the Arctic high seas, particularly in the central Arctic Ocean. As a distant water fishing entity which is likely to see its vessels move into the central Arctic Ocean high seas area, the EU would be well placed to push for the establishment of an MPA there, if not in the other Arctic high seas enclaves. In the meantime the negotiations of this instrument provide the EU with an opportunity for action. It is suggested that the EU should keep working towards the adoption of this new implementing protocol. As a member of the CBD, it is also in a position to promote a cross-sector MPA around the North Pole within the CBD regime and it may use the coordination process discussed earlier to pursue agreement through the Arctic Council for a programme of measures aimed at the establishment of an MPA in the central Arctic Ocean, if not more widely within the Arctic waters.

\section{Conclusions}

Arctic marine biodiversity is under threat as a result of the possibility of increased human activities in the Arctic, following the impacts of climate change on Arctic ice. Although there is a comprehensive international legal regime applicable to the marine Arctic, gaps do exist for the protection of marine biodiversity in the Arctic. The EU, as a major actor in international environmental politics and decision-making, has competence to take initiatives to improve the current legal regime.

This paper has outlined a number of potential ways in which the EU may be able to play an influential role. In doing so it has highlighted the fact that the EU's chances of successfully

\footnotetext{
152 Summary of the Seventh Meeting of the Working Group on Marine Biodiversity Beyond Areas of National Jurisdiction: 1-4 April 2014, Briefing Note on the WG on Marine Biodiversity, IISD, 7 April, 2014, 1.
} 
taking measures to protect Arctic marine biodiversity are higher than one might initially anticipate, given that its status as an Arctic actor is often times in question by Arctic States. It has also highlighted the fact that the greatest opportunities for successful action may not lie in the most immediately obvious locations. Thus one might anticipate that the EU should push for observer status within the Arctic Council to be able to influence decision-making there, or that it should pursue action under the CBD, or climate change regimes. It is, however, likely to prove extremely difficult to get agreement on Arctic specific measures in either the CBD or climate change regime, and the possibility of usefully influencing the development of agreements within the Arctic Council seem somewhat slight. There are, however, alternative options and chief amongst these in terms of likely success is the adoption of internal measures to regulate shipping, extractive industries or fisheries in the Arctic. That is not to say that action within the CBD or elsewhere should be written off completely, simply that, as the chances of success are less certain, they may not be the best places to start. 